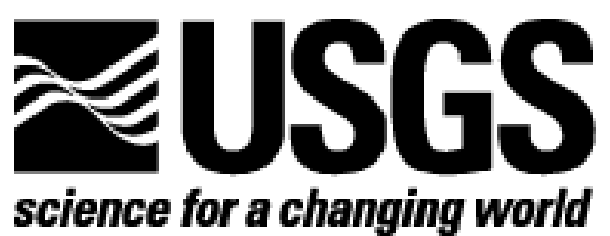

\title{
Geochemistry of bedrock and glacial deposits in the vicinity of the Bend massive sulfide deposit, north central Wisconsin
}

\author{
By Laurel G. Woodruff', John W. Attig ${ }^{2}$, William F. Cannon³, Suzanne W. \\ Nicholson $^{3}$ and Klaus Schulz ${ }^{3}$
}

Open-File Report 03-353

2003

This report is preliminary and has not been reviewed for conformity with U.S. Geological Survey editorial standards. Any use of trade, firm, or product names is for descriptive purposes only and does not imply endorsement by the U.S. Government.

\author{
U.S. DEPARTMENT OF THE INTERIOR \\ U.S. GEOLOGICAL SURVEY \\ ${ }^{1}$ U.S. Geological Survey, 2280 Woodale Drive, Mounds View, MN 55112 \\ ${ }^{2}$ Wisconsin Geological and Natural History Survey, Madison, WI 53711 \\ ${ }^{3}$ U.S. Geological Survey, MS 954, Reston, VA 20192
}




\section{INTRODUCTION}

In 1998 the U.S. Geological Survey (USGS) initiated a study to examine the natural regional environmental impact of sulfide mineralization exposed to episodic weathering and glaciation. The study focused on the Bend copper-gold massive sulfide deposit located in the Medford District of the Chequamegon National Forest in north central Wisconsin. The Bend massive sulfide deposit is a small, metal-rich sulfide body hosted by Paleoproterozoic metavolcanics. The mineralized horizon subcrops beneath 100-120 feet of glacial cover, and consists of massive pyrite and other sulfides. Bedrock and ore geochemistry are well characterized by analyses of diamond drill core provided to the USGS by Sharpe Energy and Resources.

In July 1999, five rotosonic drillholes were completed through the unconsolidated Quaternary sediment, averaging about 100 feet thick, on a transect across the Bend deposit. Nearly continuous core was recovered from the surficial material along with several feet of the underlying bedrock. Samples representing the entire section were analyzed by the USGS to give a two-dimensional representation of element dispersal from the unmineralized bedrock. In addition, one hundred regional till samples were subsampled from the archives of the Quaternary Sediment Laboratory in the University of Wisconsin-Madison Department of Geology and Geophysics. These regional samples were collected mainly from Taylor County, where the Bend deposit is located, as well as contiguous parts of Clark and Marathon Counties.

This open file report presents all of the geochemical data collected for this study. Additional publications describing the data in more detail are being completed.

\section{BEDROCK AND GLACIAL GEOLOGY}

The Bend deposit is one of a number of undeveloped massive sulfide deposits located within the Paleoproterozoic (1889 to $1835 \mathrm{Ma}$ ) Ladysmith-Rhinelander metavolcanic complex. The complex is a group of rocks that occur across much of north central and northeastern Wisconsin (Figure 1). The Ladysmith-Rhinelander metavolcanic complex and related rocks are interpreted to have formed in an island arc-back arc setting (Sims and others, 1989). In the area of the Bend massive sulfide deposit, regional bedrock is a steeply dipping, interbedded sequence of schistose rhyolite and rhyodacite lava flows, and quartz-crystal tuffs that were regionally metamorphosed to lower greenschist and amphibolite grade.

Sulfide mineralization and associated alteration (sericitization and silicification) at the Bend deposit resulted from multiple hydrofluid discharges onto the sea floor as well as subsurface replacements within a fossil fumarole system. The identified deposit consists of a series of steeply dipping, stacked massive to semi-massive, copper-goldbearing pyritic sulfide lens. Ore minerals include variable amounts of chalcopyrite and lesser tetrahedrite-tennantite, bornite and gold-silver tellurides. Geochemistry for this suite of sulfide minerals is similar to many other gold-rich " $\mathrm{Cu}$ type" volcanogenic massive sulfide deposits in the world, with high values of arsenic, bismuth, mercury, tellurium, thallium, and antimony in the mineralization (DeMatties, 1994). Gossan and mineralized saprolite have developed along the approximately 1000-foot strike length of the mineralization where it approaches and intersects the bedrock subcrop surface.

The area of Wisconsin around the Bend deposit has been glaciated several times during the Quaternary, most recently during the Wisconsin Glaciation. Ice last wasted 
from the region 15,000 years ago (Attig, 1993). Surficial glacial sediments across much of northern Wisconsin belong to the Copper Falls Formation, which had it source in the Lake Superior region. In much of Taylor County, which includes the Bend deposit, the Copper Falls Formation overlies deposits of the older, pre-Wisconsin Marathon Formation, which had a source in the shale and limestone bedrock of central Canada (Attig, 1993) (Figure 1). In the immediate vicinity of the Bend deposit, core from the five rotasonic boreholes (Figure 2) reveal a complex glacial stratigraphy with numerous intervals of till, outwash and lake deposits.

\section{METHODS OF STUDY}

\section{Sample Collection and Preparation}

Geochemical sample media analyzed for this study include nonmineralized bedrock, mineralized bedrock, massive sulfide and glacial materials. All rock and glacial samples were shipped to the USGS analytical laboratories in Denver, CO for sample preparation. Methods for sample preparation for analysis are described here and in more detail in Taggert (2002).

\section{Rocks}

Rock and massive sulfide samples were collected from available drill core. Between 1976 and 1994 diamond drilling was conducted on the Bend deposit by a consortium of exploration companies that formed the Jump River Venture; by 1994 only Sharpe Energy and Resources remained in the Venture. Core logs provided by Sharpe were used to select regional, and mineralized as well as altered rock samples collected for most lithologies present to characterize mineralization and surrounding host rocks.

Sample splits from the diamond drill core were crushed to $0.5 \mathrm{~cm}$ fragments in a jaw crusher and fed into a ceramic plate pulverizer where fragments were reduced to approximately minus 100-mesh. Each pulverized sample was split, with a portion submitted for geochemical analysis and a portion archived. Clean quartz rock and sand were crushed and pulverized between samples to minimize cross-contamination.

\section{Glacial Materials}

Regional till samples were collected as part of a study of the Pleistocene geology of Taylor County, Wisconsin (Attig, 1993). Till samples were taken from splits stored in a repository at the Quaternary Laboratory in the Department of Geology and Geophysics at the University of Wisconsin-Madison. Samples were collected from outcrops and from the bit of a solid-stem auger or from split-spoon corers advanced ahead of a hollow-stem auger. Multiple samples often were collected from a single borehole. Samples were described in the field and then analyzed in the Quaternary Laboratory. Grain-size distribution of the less-than-2mm fraction was determined using dry sieve and hydrometer techniques. Munsell color and magnetic susceptibility were also determined in the laboratory using standard techniques.

Core samples of the unconsolidated deposits overlying bedrock in the immediate vicinity of the Bend massive sulfide deposit were collected from five rotasonic boreholes (Figure 2) drilled for this project. The locations for the rotasonic boreholes were constrained by access along Forest Road 112, but were selected to be both up-ice (Borehole Ta-1) and down-ice (Boreholes Ta-3, -4, and -5) from the subcrop trace of mineralization), as well as directly over the area of mineralization (Borehole Ta-2) (Figure 2). Core was extracted from the holes in 10-foot intervals and transported in 
plastic bags to a nearby core storage facility where the core was split and logged. Sampling intervals were determined by changes in the nature of the glacial deposits. Samples collected for grain-size distribution of the less-than-2mm fraction, Munsell color and magnetic susceptibility were analyzed at the Quaternary Laboratory at the University of Wisconsin using standard techniques. Samples collected for geochemical analysis typically were composited from continuous intervals of similar material and sent the U.S. Geological Survey Laboratories in Denver, CO for processing.

\section{Geochemical Analytical Techniques}

A large number of chemical elements were determined using a variety of quantitative analytical techniques. All geochemical analyses were done at the USGS contract analytical laboratory, XRAL Laboratories, Don Mills, Ontario, Canada. Quality assurance/quality control (QA/QC) concerns were addressed through the use of internal reference standards and analytical duplicates for all samples processed by the USGS. Standard procedures require that QA/QC samples comprise about 10 percent of the total number of samples analyzed. Reference standards were interspersed with each batch of samples submitted for analysis. Values for the reference standards were checked to assure that reported values are within $+/-20$ percent of the accepted standard values. Analytical duplicates were included with each batch of samples. Duplicate analyses were checked to assure that the relative percent difference between duplicates was no greater than $20 \%$ for individual elements.

Each of the techniques used by XRAL is described in detail in Taggert (2002).

\section{Summary of XRAL Geochemical Techniques \\ Atomic Absorption Spectrophotometry (AAS)}

Antimony (Sb), arsenic (As), selenium (Se), tellurium (Te) and thallium (Tl) were all analyzed by hydride generation atomic absorption spectrophotometric techniques. For arsenic and antimony, samples are mixed with sodium peroxide and heated in a muffle furnace set at $750^{\circ} \mathrm{C}$ for four minutes. The sample is cooled then $15 \mathrm{ml}$ of water and $5 \mathrm{ml}$ of concentrated $\mathrm{HCl}$ is added. The mixture is shaken and $0.25 \mathrm{ml}$ of an ascorbic acid $\mathrm{KI}$ solution is added then diluted with $20 \% \mathrm{HCl}$ and let to stand overnight. The lower detection limit for both $\mathrm{As}$ and $\mathrm{Sb}$ is $0.6 \mathrm{ppm}$.

Selenium and tellurium are determined by adding the sample to a mixture of nitric, hydrofluoric and perchloric acids and heating. After the solution is cooled hydrochloric and nitric are added, heated again and cooled, after which the sample is analyzed. The lower detection limit for Se is $0.2 \mathrm{ppm}$ and for Te is $0.1 \mathrm{ppm}$.

Thallium is determined by weighing $0.1 \mathrm{~g}$ of sample into a zirconium crucible. Approximately $0.75 \mathrm{~g}$ of sodium peroxide is added and mixed. The mixture is heated in a muffle furnace set at $750^{\circ} \mathrm{C}$ for four minutes. The sample is cooled then $15 \mathrm{ml}$ of water

and $5 \mathrm{ml}$ of concentrated $\mathrm{HCl}$ is added. The mixture is shaken and $0.25 \mathrm{ml}$ of an ascorbic acid $\mathrm{KI}$ solution is added then diluted with $20 \% \mathrm{HCl}$ and let to stand overnight before analysis. The lower detection limit for $\mathrm{Tl}$ is $0.1 \mathrm{ppm}$.

\section{Automated Sulfur Analyzer (ASA)}

Total sulfur (S) was determined using an automated sulfur analyzer. Approximately $0.25 \mathrm{~g}$ sample is weighed and mixed with $1 \mathrm{~g}$ vanadium pentoxide flux. The sample is combusted in an oxygen atmosphere at $1350^{\circ} \mathrm{C}$ where the sulfur oxidizes 
to sulfur dioxide. Moisture and dust are removed and a solid-state infrared detector then measures the sulfur dioxide gas. The lower reporting limit for $\mathrm{S}$ is $0.05 \%$.

\section{Columetric Titration}

Samples were analyzed for carbonate carbon by coulometric titration. The sample is treated with hot $2 \mathrm{~N}$ perchloric acid and the evolved $\mathrm{CO}_{2}$ is passed into a cell containing a solution of monoethanolamine. The $\mathrm{CO}_{2}$, quantitatively absorbed by the monoethanolamine, is coulometrically titrated using platinum and silver/potassium iodide electrodes. The lower reporting limit is $0.01 \%$.

Some rock samples were analyzed for ferrous oxide $(\mathrm{FeO})$ by digesting the powdered rock with with a mixture of sulfuric, hydrofluoric, and hydrochloric acids. The solution is titrated with potassium dichromate using sodium diphenylanime sulphonate indicator. The lower detection limit is $0.01 \%$.

\section{Continuous Flow-Cold Vapor Atomic Absorption Spectrometry}

For mercury $(\mathrm{Hg})$ analyses, samples were digested with nitric acid and sodium dichromate in a disposable test tube and diluted with water. Samples are then mixed with air and a sodium chloride-hydroxylamine hydrochloride-sulfuric acid solution and $\mathrm{Hg}$ (II) is reduced to $\mathrm{Hg}^{\circ}$ with stannous chloride in a continuous flow manifold. The mercury vapor is separated and measured using continuous-flow cold vapor-atomic absorption spectrometry. The lower detection limit for $\mathrm{Hg}$ is $0.02 \mathrm{ppm}$

\section{Essential and Nonessential Water}

Essential water $\left(\mathrm{H}_{2} \mathrm{O}^{+}\right)$is determined by drying the sample for 1 hour at $105 \pm$ $5^{\circ} \mathrm{C}$ to remove $\mathrm{H}_{2} \mathrm{O}$ (hydroscopic water). Then the sample is heated at $950^{\circ} \mathrm{C}$ by using a tube furnace. The $\mathrm{H}_{2} \mathrm{O}^{+}$is absorbed by magnesium perchlorate. From its gain of weight the amount of combined water is calculated. Non-essential water $\left(\mathrm{H}_{2} \mathrm{O}^{-}\right)$is determined by drying the sample for 2 hours at $105 \pm 5^{\circ} \mathrm{C}$, from the loss in weight, non-essential water, in percent, is calculated. The lower reporting limit is $0.05 \%$ for both forms of water. Total water is the sum of the two constituents.

\section{Fire Assay}

Gold ( $\mathrm{Au}$ ) was determined by atomic absorption spectrophotometry after collection by fire assay. An assay fusion consists of heating a mixture of the finely pulverized sample with about three parts of a flux until the product is molten. One of the ingredients of the flux is a lead compound which is reduced by other constituents of the flux or sample to metallic lead. The latter collects all the gold, together with silver, platinum metals, and small quantities of certain base metals present in the sample and falls to the bottom of the crucible to form a lead button. The gangue of the ore is converted by the flux into a slag sufficiently fluid so that all particles of lead may fall readily through the molten mass. The choice of a suitable flux depends on the character of the ore. The lead button is cupelled to oxidize the lead leaving behind a dore bead containing the precious metals. The dore bead is then transferred to a test tube, dissolved with aqua regia, diluted to a specific volume and determined by atomic absorption spectrophotometry. The lower detection limit for $\mathrm{Au}$ is $5 \mathrm{ppb}$.

\section{Inductively Coupled Plasma-Atomic Emission Spectroscopy}

Forty major, minor, and trace elements were determined in rocks and mineral soils by inductively coupled plasma-atomic emission spectrometry. Each sample was digested using a mixture of hydrochloric, nitric, perchloric, and hydrofluoric acids at low 
temperature. The digested sample was aspirated into the ICP-AES. Analyzed elements and lower detection limits are given in Table 1.

\section{DESCRIPTION OF DATA FILES}

The analytical data files are provided as five separate Microsoft Excel 2000.xls files. The five files are:

1) Bend_regional.xls Analyses of rock samples taken from diamond drill core. Samples are representative of the Ladysmith-Rhinelander metavolcanic country rock in the vicinity of the Bend massive sulfide deposit.

2) Bend_deposit.xls Analyses of mineralized and altered rock associated with massive sulfide mineralization at the Bend deposit.

3) Bend_massive_sulfide.xls Analyses massive sulfide from the Bend deposit.

4) Regional_till.xIs Analyses of till samples collected in the region around the Bend massive sulfide deposit, including samples from Taylor, Marathon and Clark counties.

5) Rotasonic_core.xls Analyses of unconsolidated glacial material and regolith collected from five rotasonic boreholes drilled in the immediate vicinity of the Bend massive sulfide deposit. Included are geochemical analyses on samples collected by the USGS and physical characteristics determined from separate, but comparable samples collected by John Attig of the Wisconsin Geological and Natural History Survey (WGHNS).

\section{Common Data Fields}

In all data tables the following abbreviations are used as needed: ins. = insufficient sample for analysis; dup. = duplicate sample.

\section{Field Number}

Field numbers are given for all bedrock, mineralized rock, and glacial samples. For samples taken from diamond drill core the Field Number consists of the drill hole number and the footage (down hole) where the sample was collected. For the regional till samples the first letters in the Field Number indicates the county where the sample was collected $(\mathrm{Cl}=$ Clark, $\mathrm{Ma}=$ Marathon, and $\mathrm{Ta}=$ Taylor $)$ and the final two numbers show the year the sample was collected. For the rotasonic core the Field Number indicates the borehole number (Ta-1 through Ta-5).

\section{Coordinates}

Latitude and longitude for sample site locations are given in the data tables as decimal degrees. The coordinates for the diamond drill core samples are for the location of the drill hole collar. Coordinates for the rotasonic holes were determined by GPS and all holes were vertical.

\section{Geochemical Analyses}

All geochemical data are given in the following format. Field identifiers consist of three lines. The first line gives the chemical element symbol and unit of measurement. The second line is an abbreviated code for the analytical technique used for the element in that particular column. Reporting units are weight percent (wt. \%) or parts per million (ppm). The analytical methods codes are:
AAS
atomic absorption spectrophotometry
ASA
automated sulfur analyzer 

CT
columetric titration
CV-AAS
cold-vapor atomic absorption spectrophotometry for mercury
FA
ICP-AES
gold by fire assay and atomic absorption spectrophotometry
inductively coupled plasma-atomic emission spectroscopy

The third line lists the laboratory (XRAL or WGHNS) where the analyses were done.

\author{
Unique Data Fields \\ Individual data files have several unique fields. \\ Bend_regional.xls \\ Rock Description \\ Bend_deposit.xls \\ Rock Description \\ Bend_massive_sulfide.xls \\ Rock Description \\ Regional till.xls \\ Sample Depth (feet) \\ Glacial Deposit Designation

\section{Rotasonic_core.xls \\ Depth Interval} \\ Field Description \\ Glacial Formation \\ rock lithology determined from drill logs and field notes \\ rock lithology determined from drill logs and field notes \\ ore description \\ estimated depth from which sample was collected in \\ auger hole \\ the name of the glacial formation and member (if \\ known) for each sample - descriptions of each unit are \\ given in Attig (1993) \\ depth from which the sample was collected - samples \\ typically were composited over the entire interval given \\ nature of glacial material or bedrock as determined from \\ core logging in the field \\ name of the glacial formation determined from core \\ logging in the field, based on observable characteristics
}

\title{
ACKNOWLEDGEMENTS
}

Sharpe Energy and Resources provided diamond drill core, drill logs, and additional information on the Bend massive sulfide deposit through the auspices of Ted DeMatties. Randy Rabideaux and Greg Knight of the USDA Forest Service provided assistance for National Forest access and rotasonic drilling permitting. Doug Ottke, formerly of the USGS, provided able field assistance. Connie Dicken and Art Schultz of the USGS and Ted DeMatties provided reviews of text and tables.

\section{REFERENCES}

Attig, J.W., 1993, Pleistocene geology of Taylor County, Wisconsin. Wisconsin Geological and Natural History Survey Bulletin 90.

DeMatties, T.A., 1989, A proposed geologic framework for massive sulfide deposits in the Wisconsin Penokean volcanic belt. Economic Geology, v. 84, p. 946-952.

Sims, P.K., Van Schmus, W.R., Schulz, K.J. and Peterman, Z.E., 1989, Tectonic-stratigraphic evolution of the early Proterozoic Wisconsin magmatic terranes of the Penokean Orogen. Canadian Journal of Earth Science, v. 26, p. 2145-2158.

Taggert, J.E., Jr., 2002, Analytical methods for chemical analysis of geologic and other materials, U.S.

Geological Survey: U.S. Geological Survey Open-File Report 02-0223. 
Table 1. Lower detection limits for 40-element ICP-AES method.

\begin{tabular}{|c|c|}
\hline Element & Lower detection limit \\
\hline Aluminum, $\mathrm{Al}$ & $0.005 \%$ \\
\hline Calcium, $\mathrm{Ca}$ & $0.005 \%$ \\
\hline Iron, Fe & $0.02 \%$ \\
\hline Potassium, $\mathrm{K}$ & $0.01 \%$ \\
\hline Magnesium, Mg & $0.005 \%$ \\
\hline Sodium, $\mathrm{Na}$ & $0.005 \%$ \\
\hline Phosphorous, $\mathrm{P}$ & $0.005 \%$ \\
\hline Titanium, Ti & $0.005 \%$ \\
\hline Silver, Ag & $2 \mathrm{ppm}$ \\
\hline Arsenic, As & $10 \mathrm{ppm}$ \\
\hline Gold, Au & $8 \mathrm{ppm}$ \\
\hline Barium, $\mathrm{Ba}$ & $1 \mathrm{ppm}$ \\
\hline Beryllium, Be & $1 \mathrm{ppm}$ \\
\hline Bismuth, Bi & $10 \mathrm{ppm}$ \\
\hline Cadmium, Cd & $2 \mathrm{ppm}$ \\
\hline Cerium, $\mathrm{Ce}$ & $5 \mathrm{ppm}$ \\
\hline Cobalt, Co & $2 \mathrm{ppm}$ \\
\hline Chromium, $\mathrm{Cr}$ & $2 \mathrm{ppm}$ \\
\hline Copper, $\mathrm{Cu}$ & $2 \mathrm{ppm}$ \\
\hline Europium, Eu & $2 \mathrm{ppm}$ \\
\hline Gallium, Ga & $4 \mathrm{ppm}$ \\
\hline Holmium, Ho & $4 \mathrm{ppm}$ \\
\hline Lanthanum, La & $2 \mathrm{ppm}$ \\
\hline Lithium, Li & $2 \mathrm{ppm}$ \\
\hline Manganese, Mn & $4 \mathrm{ppm}$ \\
\hline Molybdenum, Mo & $2 \mathrm{ppm}$ \\
\hline Niobium, $\mathrm{Nb}$ & $4 \mathrm{ppm}$ \\
\hline Neodymium, $\mathrm{Nd}$ & $9 \mathrm{ppm}$ \\
\hline Nickel, Ni & $3 \mathrm{ppm}$ \\
\hline Lead, $\mathrm{Pb}$ & $4 \mathrm{ppm}$ \\
\hline Scandium, Sc & $2 \mathrm{ppm}$ \\
\hline Tin, Sn & $5 \mathrm{ppm}$ \\
\hline Strontium, $\mathrm{Sr}$ & $2 \mathrm{ppm}$ \\
\hline Tantalum, Ta & $40 \mathrm{ppm}$ \\
\hline Thorium, Th & $6 \mathrm{ppm}$ \\
\hline Uranium, U & $100 \mathrm{ppm}$ \\
\hline Vanadium, V & $2 \mathrm{ppm}$ \\
\hline Yttrium, Y & $2 \mathrm{ppm}$ \\
\hline Ytterbium, Yb & $1 \mathrm{ppm}$ \\
\hline Zinc, Zn & $2 \mathrm{ppm}$ \\
\hline
\end{tabular}

